\title{
CURHAT DI BALIK LACI: EKSPRESI LITERASI SISWA DI MADRASAH ALIYAH PESRI KENDARI
}

\author{
VENT BEHIND THE DESK DRAWER: \\ THE LITERACY EXPRESSION OF STUDENT AT MA PESRI KENDARI
}

\author{
Abu Muslim \\ Peneliti Balai Penelitian dan Pengembangan Agama Makassar \\ Jl. AP. Pettarani No. 72 Makassar \\ abumuslim@kemenag.go.id
}

Naskah diterima tanggal 4 Maret 2019, Naskah direvisi tanggal 30 April 2019, Naskah disetujui tanggal 30 Mei 2019

\begin{abstract}
Abstrak
Tulisan ini menyajikan hasil penelitian tentang pengembangan budaya literasi siswa melalui pengejawantahan petuah bijak yang diekspresikan dari berbagai media. Penelitian ini menggunakan metode kualitatif deskriptif untuk mengungkap pemanfaatan petuah bijak dalam pengembangan budaya literasi siswa Madrasah Aliyah, dengan memilih secara purposif MA Pesantren Ummushabri Kota Kendari sebagai lokus pengamatan. data dikumpulkan dengan metode wawancara, dan observasi, serta melaksanakan FGD di Madrasah sasaran. Teori representasi dipilih sebagai pisau analisis untuk mengungkap makna dibalik karya siswa yang mengandung petuah-petuah bijaksana sebagai sarana motivasi diri, yang dituliskan pada media-media tertentu. Pengumpulan data dilakukan selama kurang lebih 18 hari (5 hari penjajakan +13 hari pengumpulan data) di bulan Agustus 2016. Hasil kajian menemukan bahwa pengembangan budaya literasi siswa di MA PESRI dapat dilihat pada kreasi berbasis inisiatif yang dituliskan siswa pada berbagai media. Hasil kreasi tersebut mengandung keluh-kesah sebagai simbol beratnya beban yang harus diemban oleh siswa atas ketatnya aturan-aturan pesantren. Penelitian ini juga melihat transformasi pemaknaan dari siswa atas petuah bijak masa lalu, yang didesain ulang dengan tata bahasa yang dibuat sendiri sebagai simbol motivasi dan ekspresi bijaksana, yang bisa ditemui di balik laci, dan pintu-pintu lemari, serta tempat-tempat lainnya. Dalam aspek yang lebih luas, coretan-coretan itu menggambarkan semangat juang tinggi dari para anak-anak pesantren di kehidupan yang sangat dinamis dan penuh liku.
\end{abstract}

Kata Kunci: literasi, petuah bijak, pesantren, madrasah aliyah

\begin{abstract}
This paper presents the results of research on the development of students' literacy culture through the wisdom of wisdom advocates expressed from various media. This research uses descriptive qualitative method to reveal the use of wise advice in the development of literacy culture of Madrasah Aliyah students, by purposively choosing MA Pesantren Ummushabri Kendari City as the locus of observation. data were collected by interview method, and observation, and conducted FGD in target Madrasah. Theory of representation is chosen as an analytical tool to reveal the meaning behind the student's work containing wise advice as a means of self-motivation, written on certain media. Data collection was conducted for approximately 18 days (5 days of assessment +13 days of data collection) in August 2016. The results of the study found that the development of literacy culture of students in MA Pesri can be seen on the initiative-based creations written by students on various media. The results of these creations contain complaints as a symbol of the heavy burden that must be assumed by students on the strict rules of boarding. The study also looks at the meaningful transformation of students of the past, redesigned wisdom of the past with a self-made grammar as a symbol of motivation and wise expression, which can be found behind drawers, cabinet doors, and other places. In a broader aspect, the graffiti illustrates the high morale of santri in a life that is very dynamic and full of twists.
\end{abstract}

Keywords: literacy, wisely wisdom, boarding school, the madrasah of aliyah 


\section{PENDAHULUAN}

$\mathrm{K}$

ekuatan literasi adalah spirit untuk membangkitkan peradaban bangsa, for Internationa Studen for International Student Assessment (PISA) menyebutkan, budaya "literasi" masyarakat Indonesia tahun 2012 berada pada urutan ke 64 dari 65 negara. Ditambah lagi dengan data statistik UNESCO 2012 menyebut indeks minat baca di Indonesia baru mencapai 0,001. Artinya, setiap 1.000 penduduk, hanya satu orang saja yang memiliki minat baca. Hal ini juga tentu berpengaruh dalam dunia pendidikan mana pun di Indonesia yang merupakan basis utama dalam pengembangan budaya literasi (Pramono, 2016).

Upaya strategis yang bisa dilakukan untuk menumbuhkan daya literasi Indonesia secara menyeluruh dan berkesinambungan adalah dengan memulainya dari pendidikan di sekolah. Pendidikan yang berbasis pada kemampuan nalar, belakangan menjadi isu yang gencar disuarakan para ahli pendidikan. Prof. Iwan Pranoto, guru besar matematika ITB, misalnya dalam sejumlah tulisannya mengingatkan tentang pendidikan bernalar. Kemampuan bernalar dalam konteks ini mencakup daya berpikir logis, keterampilan mengolah informasi dari bacaan, dan kemampuan menyimpulkan pemikiran sendiri (Wardi, 2013). Lebih lanjut dikemukakan bahwa untuk bisa berdaya literasi tinggi, siswa diandaikan bukan hanya bisa baca dan tulis, melainkan juga aktif dalam memaknai teks, mengerti fungsi penggunaannya, dan menganalisis teks secara kritis, serta mentransformasi penggunaannya (Luke dan Feebody; Programme for International Student Assessment (PISA) (Wardi, 2013) (Luke dan Feebody, 2013).

Salah satu sumber pengembangan literasi dapat ditelusuri dalam petuah bijak sebagai tradisi yang bermuatan nilai luhur dan bercitra arketipe, yang bisa mengarahkan perilaku, khususnya yang berkaitan dengan pikiran dan perasaan secara tidak langsung, seperti cita-cita dan kehendak, kreasi dan imajinasi, khususnya perilaku yang peka zaman perlu dilestarikan dan dipopulerkan dalam kalangan siswa (Ratna, 2011). Pengembangan terhadap petuah bijak yang diilhami dari pemaknaan pesan-pesan luhur menjadi sesuatu yang sangat potensial untuk didesain ulang melalui ragam ekspresi dalam segenap karyakarya yang dihasilkan. Oleh karena itu, melacak dan melihat kembali segenap tulisan-tulisan siswa, sebagai ekspresi keaksaraan mereka dalam membaca dan menghadapi zaman modern, menjadi penting untuk dilakukan. Sebab boleh jadi, di dalam setiap tulisan-tulisan itu, akan dijumpai remah-remah kebijaksanaan, kekuatan-kekuatan motivasi, bahkan ajakanajakan positif dari mereka demi menjadi generasi yang tegar, dan peka zaman.

Selanjutnya, penelitian ini dilakukan dalam rangka mengidentifikasi pengembangan budaya literasi generasi muda, hal ini menunjuk pada pemilihan siswa sebagai representasi kaum muda. Karena itulah problem penelitian ini dititikberatkan pada bagaimana petuah bijak itu diekspresikan oleh siswa untuk pengembangan budaya literasi. Secara teknis rumusan masalah ini dijabarkan sebagai berikut:

Bagaimanakah varian petuah bijak yang dijumpai pada siswa? (2) Bagaimana ekspresi petuah bijak itu diejawantahkan dalam pengembangan budaya literasi?

Tulisan ini difokuskan pada penelusuran petuah bijak siswa. Pengejawantahannya diawali dengan melakukan semacam inventarisasi petuah bijak yang tersebar di lingkungan madrasah, serta petuah bijak lainnya yang diketahui oleh para siswa. Selanjutnya, melakukan analisis dan 'pembacaan' (pemisahan dan atau pengelompokan) terhadap petuah bijak itu, demi melihat polarisasi kandungan nilainya, atau kecenderungan pemikiran para siswa, baik berupa pesan atau ekspresi dari siswa atas lingkungan, atau perasaannya terhadap sesuatu, yang diartikulasikan melalui tulisan/bahasa.

\section{Tinjauan Pustaka}

Petuah bijak yang dimaksudkan dalam penelitian ini adalah folklor lisan yang terdiri atas; 1) ungkapan tradisional, (pepatah, peribahasa, semboyan). 2) nyanyian rakyat. 3) bahasa rakyat berupa dialek, julukan, sindiran, bahasa rahasia, bahasa remaja, dan sejenisnya. 4) teka-teki (berbagai bentuk tanya jawab pada 
umumnya untuk mengasah pikiran). 5) cerita rakyat; mite, legenda, sage (Hutomo, 1991). Sementara itu, ekspresi literasi adalah apa-apa saja yang diekspresikan siswa dalam tulisantulisannya sebagai pengejawantahan atas pembacaan dan atau pengalamannya terhadap sesuatu, yang mengandung unsur pesan-pesan di dalamnya (Latifah, 2014). Tulisan itu bisa dalam bentuk cerita, novel, catatan-catatan, atau bahkan dalam bentuk quote berbasis media sosial.

Penelitian terkait petuah bijak pernah dilakukan oleh Balai Penelitian dan Pengembangan Agama Makassar, dengan judul "Nilai-nilai Keagamaan dalam Petuah Bijak, Puisi dan Peribahasa Kawasan Timur Indonesia. Hasil penelitian ini mengungkapkan beberapa varian petuah bijak dari beberapa daerah di kawasan Indonesia timur mengandung nilai-nilai kearifan lokal antara lain (Asad dkk, 2012): nilai-nilai keagamaan pada kelong Makassar, oleh Muhammad As'ad. 2). Akhlak pemimpin dalam Tuja'I penganugerahan gelar adat pulanga di Gorontalo, oleh Husnul Fahimah. 3). Rukun Islam dalam kalindaqdaq, oleh Idham. 4). Nilai keagamaan dalam lagu daerah Kaili Sulawesi Tengah, oleh Muh Subair. 5). Artikulasi Religi Sajak-Sajak Basudara di Ambon, oleh Abu Muslim (Muslim, 2013). 6). Paiya Lohungo lopoli, petuah bijak dalam pantun Gorontalo, oleh Paisal. 7). Nilai keagamaan dalam tevai ntoutua pada etnis Kaili di Kota Palu, oleh Muhammad Sadli Mustafa. 8). Nilai-nilai Keagamaan dalam sengo-sengo di Mambi Mamasa Sulbar, oleh La Mansi.

Suyono mengungkapkan bahwa literasi dapat dijadikan sebagai basis pengembangan pembelajaran efektif dan produktif di sekolah. Konteks yang mendasarinya adalah bahwa literasi memungkinkan siswa banyak membaca dan terampil mencari dan mengolah informasi, sehingga kemampuan siswa membaca dan menulis menjadi berkembang (Suyono, 2009).

Posisi penelitian ini lebih jauh akan melihat bagaimana literasi menggugah perasaan siswa. Sehingga penelitian terdahulu yang terkait literasi akan dijadikan sebagai pendukung dan penguat, di mana fakta-fakta yang dikemukakan sangat mendukung adanya literasi sebagai sumber inspirasi nilai-nilai luhur, petuah bijak dan merupakan modal bagi siswa untuk mengembangkan potensi dirinya dan menguatkan kepribadiannya.

Secara tradisional, literasi didefinisikan sebagai dunia berbasis cetak (dunia buku dan media cetak lainnya), dunia cetak dan/atau gambar dua dimensi (New South Wales Department of Education and Training, 2010). Literasi selalu berhubungan dengan kemampuan membaca dan menulis. Definisi terdahulu dianggap tidak lagi dapat mengakomodasi caracara baru dari sebuah makna, seperti mencari informasi di beberapa modalitas, berpartisipasi dalam konferensi audio visual, korespondensi email, lingkungan virtual, membuat situs pribadi, blog atau wikipedia. Jenkins (2006) mendefinisikan keterampilan literasi/keaksaraan di abad dua puluh satu sebagai sebuah keterampilan yang memungkinkan partisipasi dalam komunitas baru yang muncul dalam jaringan masyarakat (Jenkins, 2006). Sehubungan dengan ini, Hill (2006) menyatakan bahwa literasi membaca, menulis, berbicara dan mendengarkan, tentu sangat perlu melibatkan pengetahuan dan keterampilan yang dibutuhkan agar dapat berfungsi efektif di dalam masyarakat (Hill, 2006). Peserta didik perlu untuk terus membangun kemahiran dasar dan keterampilan tersebut, dalam rangka untuk mengadopsi dan menyesuaikan diri pada kemahiran masa depan (Apriani, 2016).

Menurut Hall, dalam bukunya Representation: Cultural representatiton and signifying Practice, "Representation connect meaning and language to culture... Representatiton is an essential part of the process by which meaning is produced and exchanged between members of culture (Hall, 2003). Representasi adalah suatu proses untuk memproduksi makna dari konsep yang ada di pikiran kita melalui bahasa. Proses produksi makna tersebut dimungkinkan dengan hadirnya sistem representasi. Dalam penelitian ini, operasionalisasi teori representasi dapat diejawantahkan dalam mereduksi makna dalam tatanan bahasa yang dimunculkan siswa berdasarkan pengalamannya terhadap sesuatu yang kemudian dituangkan dalam coretancoretan dengan kaidah yang diciptakannya berdasarkan pembacaannya terhadap fenomena, 
bahan ajar, bahan bacaan, dan atau yang didengarkan secara langsung melalui pengarahan-pengarahan guru dan atau orang tua, yang melahirkan karya berbentuk tulisan yang berfungsi untuk memotivasi diri, atau sekadar curahan hati.

Lebih lanjut, Fairclough (1992) melihat teks dalam berbagai tingkatan yakni representasi, relasi, dan identitas. Representasi dalam pengertian Fairclough (1998) dilihat dari dua hal, yakni bagaimana seseorang, kelompok, dan gagasan ditampilkan dalam anak kalimat dan gabungan atau rangkaian antar anak kalimat. Relasi sendiri berhubungan dengan bagaimana partisipan dalam media berhubungan dan ditampilkan dalam teks. Sementara identitas ditampilkan dan dikonstruksi dalam teks, tentang bagaimana dia mengidentifikasi dirinya, dan menempatkannya dalam bangunan sosial di sekitarnya (Fairclough, 1995).

\section{METODE PENELITIAN}

Penelitian ini menggunakan metode deskriptif kualitatif untuk mendeskripsikan segenap karya-karya siswa yang merefleksikan pesan-pesan bijaksana sebagai perpanjangan tangan petuah bijak daerah, peribahasa, pepatah petitih, dan lain-lain. Selanjutnya dilakukan representasi makna yang terkandung dalam tulisan/coretan para siswa itu, demi menemukan pola keberaksaraan siswa yang sangat erat kaitannya dengan sistem budaya yang terjadi di lingkungannya (baca: madrasah/pesantren), penelitian ini juga memungkinkan melihat perilaku kebudayaan siswa melalui progres analitik terhadap setiap karya yang dihasilkan, apakah berupa cerminan sosial sehari-hari, atau malah merepresentasikan sebuah makna terselubung yang hendak disampaikan para siswa melalui coretan-coretannya. Penguatan analisis pasca pemaknaan juga dilakukan dengan melakukan elaborasi teoretis untuk melihat representasi sosial-budaya yang terjadi.

Lokasi penelitian dipusatkan di Madrasah Aliyah Pesantren Ummushabri. Pengumpulan Data dilakukan selama 13 setelah sebelumnya dilakukan penjajakan lapangan selama 5 hari. Pengumpulan data menggunakan teknik wawancara, observasi, Dokumentasi (Creswell, 1994). Informan penelitian terdiri atas informan kunci siswa, dan guru. Informan ahli akademisi, antropolog/peneliti lokal, Pakar Sosial Budaya, Pakar bahasa. Informan biasa masyarakat umum. Analisis yang digunakan dalam penelitian ini bersifat deskriptif yang bertujuan untuk membuat suatu gambaran sistematis, faktual, dan akurat mengenai faktafakta, sifat-sifat, serta hubungan antar fenomena, meskipun tidak bisa dilepaskan dari peran besar peneliti dalam memainkan fungsinya sebagai instrumen utama dalam penelitian kualitatif (Sugiyono, 2010).

\section{PEMBAHASAN}

\section{Potret Pengembangan Literasi Siswa MA PESRI}

Posisi kreativitas siswa atau sebut saja generasi muda bangsa ini, ketika diperhadapkan dengan konstruksi media sosial yang sedemikian cepat merambah dunia remaja, cenderung berada di ranah kediantaraan. Pilihannya menjadi sulit, antara menerjemahkan kreativitas itu ke arah positif meski kurang diminati, atau menggiringnya ke ranah kontroversi meski berkonotasi negatif atas nama gaul/kekinian. Mereka rentan gamang, sebab konstruksi media sosial menggiring mereka untuk terus beradaptasi dengan tren, sementara nilai-nilai luhur budaya asalnya sudah semakin jauh dari kesehariannya (baca: tidak lagi ditransformasikan). Posisi yang lebih pelik, terlihat pada sistem "deteksi kekinian" bagi para siswa di Madrasah Aliyah Pesantren Ummu Shabri Kota Kendari, mereka yang sehari-hari harus berkutat dengan konsentrasi pelajaran di madrasah dengan segala bentuk tata tertib yang melekat, juga secara bersamaan harus bisa mengadaptasi nilai-nilai keagamaan yang berlaku di lingkungan pesantren. Hal ini membuat 'koneksitas' dengan dunia luar terlihat begitu terbatas. Meskipun di dalam pesantren, mereka tetap dibekali dengan akses internet, namun hal itu hanya terbatas pada pemanfaatan yang berkaitan dengan tugas-tugas yang harus mereka selesaikan, belum lagi sarana yang serba terbatas, membuat mereka harus menggunakannya bergiliran.

"Sedapat mungkin, kita mencoba membatasi para santri untuk menggunakan hp nya di 
lingkungan pesantren, sebab meskipun terdapat hal-hal positif yang mereka bisa akses melalui perangkat smartphonenya, tetap saja kontrol terhadap penyalahgunaan akses pada hal-hal yang negatif sulit dilakukan, jika mereka dibebaskan untuk memakai internet. Itu kami lakukan, dengan keyakinan bahwa setidaknya, pembatasan itu menjauhkan mereka dari tontonan negatif dan tidak mendidik. Namun bukan berarti kami tidak menyiapkan sarana untuk mengakses internet, perangkat itu tetap kami siapkan, akan tetapi pemanfaatannya tetap harus teratur, dengan didampingi oleh guruguru, meski kami sadari keterbatasan prasarana komputer juga membuat mereka tidak bisa maksimal" (Wawancara Ibu St. Aisyah, Kepala MA PESRI Kendari) .

Realitas tersebut tentunya juga memengaruhi kreativitas para siswa untuk mengembangkan 'asa literasi' mereka. Di samping beberapa aturan yang cukup ketat itu, frekuensi pemenuhan sistem full day school yang diterapkan oleh MA PESRI, juga cukup menyita waktu para siswa/santri untuk menyesuaikan diri dengan jadwal-jadwal yang telah tersusun secara ketat. Siswa akhirnya disibukkan untuk berperan serta dalam mekanisme itu, meskipun peluang pengembangan karakter siswa dapat dilakukan di luar kelas, pada jam-jam siang-sore, padahal di waktu tersebut, pengembangan wawasan dan bakat dapat dilakukan misalnya dengan kegiatan ekstrakurikuler, yang dijadwalkan pasca proses belajar mengajar di kelas. Hanya saja, tidak banyak yang mereka bisa lakukan untuk pengembangan budaya literasi, sebab beberapa kegiatan ekstrakurikuler itu 'sudah dikapling', untuk pengembangan kesenian, olahraga, dakwah, dll.

"Sistem Full Day School dipilih sebagai konsekuensi dari swastanisasi madrasah dengan kekhasan pengelolaannya menggunakan model korporasi. Sistem Fullday school hakikatnya membantu orang tua dalam mengarahkan putraputrinya agar mengisi hari-harinya dengan kegiatan belajar dan terus belajar. Praktis terdapat kelebihan jam sekitar 4-5 jam per hari untuk dimanfaatkan dalam pengembangan bidang sains, bahasa inggris dan arab, serta keterampilan keagamaan yang menjadi ciri khas madrasah, demi membangun sumber daya manusia yang berotak Jerman dan berhati Mekah" (Anonim, Ummushabri dalam Kilasan Sejarah, dokumen tidak diterbitkan, 2016: 1-3).

Sesungguhnya, jika dimanfaatkan sedemikian rupa dengan menginisiasi programprogram khusus di bidang literasi pada jam-jam tambahan itu, maka peluang pengembangan budaya literasi pada sekolah/madrasah yang menerapkan sistem full day school bisa berkembang lebih baik dibandingkan dengan sekolah yang tidak menerapkannya.

"Selama ini, sistem pengembangan budaya literasi siswa (i) kami di Pesri lebih banyak berbentuk inisiatif dari para siswa, itu pun hanya terbatas pada keinginan tertentu, seperti karena hendak mengikuti lomba-lomba menulis cerpen dan puisi dengan hadiah yang menggiurkan, atau karena tertarik dengan kegiatan yang ditawarkan kepada mereka dari berbagai instansi, maupun lembagalembaga yang datang langsung mensosialisasikan program pengembangan sastra ke madrasah ini. Kami sebagai pembina paling hanya memberikan motivasi, atau masukan-masukan konstruktif kepada mereka dalam karya-karyanya, atau memberi motivasi untuk memulai menulis, sebab harus diakui kita tidak memiliki program pembinaan literasi yang terstruktur di sini, palingpaling, hanya mengandalkan kreasi majalah dinding, yang sangat terikat dengan hari-hari tertentu, tergantung sedang memperingati apa." (Wawancara, Nunita, Guru Bahasa Indonesia MA Pesri).

Tentu saja, dengan minimnya pembinaan berbasis program internal Pesantren yang mendukung daya jelajah siswa dalam mengembangkan kultur literasi, adalah hal lain yang juga menjadi catatan. Dengan 'hanya' terus menerus mengandalkan tawaran program dari luar, tentu membuat polarisasi pengembangan wawasan literasi siswa menjadi sangat monoton. Keberaksaraan mereka lebih banyak didominasi oleh hasrat atas hadiah yang ditawarkan, belum pada proses pencarian jati diri, dengan menjadikan menulis sebagai 'kebutuhan'.

Hal lain, yang juga menjadi problem pengembangan literasi di Madrasah Aliyah Pesri adalah minimnya buku-buku bacaan terbaru di bidang kesusastraan, sebut saja misalnya novel, dan atau gendre karya sastra lainnya. Jika pun ada, beberapa bacaan-bacaan sastra cenderung 
'dibatasi' penggunaannya hanya pada waktuwaktu istirahat dengan memanfaatkan waktu kunjung perpustakaan. Meski demikian, dalam kasus MA Pesri yang melekatkan 'konstruksi' pesantren di dalamnya, tentunya mengindikasikan sebuah persepsi yang berbeda dengan MA pada umumnya, sebab penamaan yang demikian itu, mengonotasikan MA Pesri sebagai sebuah bangunan sistem yang memiliki budayanya tersendiri, ia memosisikan sebagai sub-kultur di tengah belantika kebudayaan nusantara. Sebagaimana dimaklumi, di dalam proses pergolakan pesantren terjadi kontak interaksi, dan afiliasi yang tak sama dengan lingkungan biasa.

Di sinilah, posisi pengembangan literasi dipertaruhkan, antara berdamai dengan modernitas, atau memanfaatkan kitab-kitab klasik sebagai alternatif pengembangan wawasan literasi yang bercirikan pesantren. Tinggal bagaimana mendesain dan atau merepresentasi ciri pesantren tadi, dengan kebutuhan besar atas karya-karya siswa yang lebih bisa ditelusuri melalui karya-karya bijaksana yang telah dituliskan melalui medianya sendiri. Berikut akan digambarkan, bagaimana para siswa MA Pesri yang sehariharinya mencicipi kultur pesantren, berekreasi mengembangkan 'tulisan-tulisan' mereka sebagai bagian dari kebudayaan yang boleh jadi membuat mereka lebih kreatif. Pada penelitian ini, pengejawantahannya didahului dengan melacak potensi pemahaman umum siswa tentang petuah bijak.

\section{Peta Petuah Bijak Siswa MA PESRI}

Mengajak siswa mengingat kembali pesan-pesan luhur yang tercermin dalam petuah bijak, dewasa ini bukanlah hal yang mudah. Boleh jadi para siswa memang tidak pernah mengetahui contoh-contoh petuah bijak itu, terlebih jika berbahasa daerah. Atau mungkin mereka pernah tahu, tapi kini sudah lupa karena minimnya ruang sosialisasi dan aktualisasi bahasa daerah di sekolah. Hal yang sedikit lebih baik dijumpai ketika membincang petuah bijak dalam bahasa Indonesia, atau bahasa asing lainnya seperti bahasa Inggris dan bahasa Arab, para siswa bisa dengan mudah mengingat-ingat kembali bagaimana pesan-pesan itu menari-nari di kepalanya, jika pun teksnya tidak persis sama, setidaknya, mereka memahami maknanya dengan cukup baik. Hal ini, boleh jadi disebabkan karena pengenalan pesan-pesan itu terlihat lebih 'keren' di mata para siswa jika diserukan dalam bahasa asing. Setidaknya, itulah kesan pertama yang bisa dijumpai para tamutamu MA Pesri, ketika coba berkeliling di pelataran Madrasah. Terlihat beberapa tempelan tulisan warna-warni, di beberapa sudut dinding Madrasah, mengisyaratkan bahwa perangkat MA Pesri memanfaatkan betul anjuran-anjuran positif dari setiap petuah bijak itu untuk setidaknya memberikan motivasi kepada para siswa. Berikut beberapa teks petuah yang ditempel sedemikian rupa di MA Pesri Kendari:

- Think like a champion, and you will be champion (berpikirlah seperti seorang pemenang, dan kamu akan menjadi pemenang)

- A half hour too soon is better than a half (setengah jam terdahulu lebih baik daripada setengah menit terlambat)

- A confess in fault is gentle and honorable (mengakui kesalahan adalah suatu sikap kesatria dan kehormatan).

- Gunakanlah Waktumu Untuk Membaca

- Belajar di Waktu Kecil Bagaikan Melukis di Atas Batu, Belajar di Waktu Besar Bagaikan Melukis di Atas Air

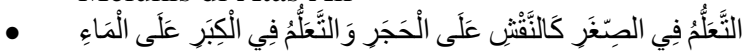

- Tekad Kami, Menggapai Hari ini Lebih Baik dari Hari Kemarin, dan Hari Esok Lebih Baik dari Hari ini.

- Mau pintar? Banyak Baca Buku Dong!

- Bagimu Guruku Pahlawanku, Persembahan Kami untuk Pahlawan Pendidikan

- Dispose of Waste in Place, Please... (Ciptakan Budaya Bersih)

Selain apa yang tertempel itu, sebenarnya kreasi dan pemahaman petuah bijak siswa MA Pesri masih cukup banyak, hanya saja diperlukan sedikit waktu untuk mengejar lebih banyak pemahaman mereka terhadap petuah bijak, khususnya yang berbahasa daerah lokal setempat. Pengetahuan itu, baru bisa dikeluarkan ketika dilakukan semacam FGD, dengan memberikan penugasan langsung kepada para siswa untuk menuliskan petuah bijak dalam bentuk form isian, hal ini mencerminkan pola kebiasaan transformasi ilmu pengetahuan siswa 
yang sudah sangat terbiasa dengan sistem induktif. Berikut daftar petuah bijak baik yang berbahasa Lokal Tolaki, Bahasa Indonesia, Bahasa Inggris, Bahasa Arab, Bahkan ada yang Berbahasa Sunda, yang telah dihimpun dari para siswa:

1. Iamo U ehe mondoihe ine suere ndono: Jangan Suka berbuat semena-mena terhadap orang lain.

2. Piarai raimu, pombeotooriamino ariamu: Peliharalah sikap dan tindakanmu, pertanda engkau berasal dari bangsa yang beradab.

3. Mombeku saramasiako meosa manusia: saling mencintai sesama manusia.

4. Uuno hina nggau-nggauno oleo haka melengge-lengge keso dowako, Haka metondowako, keto melengge-lengge: Zaman beredar, waktu berganti, keadaan akan berubah dengan pengakuan bahwa derajat, hak, dan kewajiban sesama manusia adalah sama.

5. Mosue osara peowai sala menggono: memutarbalikkan kebenaran adalah perbuatan tidak terpuji.

6. Taa moronga-ronga ehe' mombisi pisi: tidak memandang enteng orang lain.

7. Tono niperhatika, meambo torono: orang peduli, bagus hidupnya

8. Keu Ehei Meambo, Lamo u Tewali Toono mongare: Jika Engkau Ingin Bahagia (Sejahtera), Janganlah menjadi orang yang malas.

9. Gondino Sukses Laa Ine Dowomu: Kunci Sukses terletak pada dirimu sendiri.

10. Kita Sederhana, Bukan Tak Mampu

11. Mereka Bisa, Kerena mereka pikir mereka mampu, itu saja!

12. Ya Allah, Janganlah biarkan rasa cintaku pada-Mu melebihi rasa cintaku terhadap makhluk ciptaan-Mu.

13. Sing Sabar (Sunda): Harus Sabar!

14. Ulah Loba Gaya, Ari Hayang Sukses!: Jangan Banyak Gaya kalau mau sukses!

15. Ulah Gancang Mewek lamun situasina nyeredet di hati: Jangan Mudah menangis, kalau situasinya tidak enak di hati.

16. Study Now or Stupid Forever: Belajarlah Sejak dini, atau Bodoh Selamanya.

17. Mesusa Leesu Mano Meambo: Bersusahlah dulu, maka akan bagus akhirnya.

18. Attuhuru Syahtur Iman: Kebersihan Sebagian dari Iman

19. Inae Kona Sara Iyeto Tine Sara: Orang mematuhi adat akan dilayani baik.
20. Ki Porgoni o ambo i laa monaa nggomami o tambo hanggari ki peruku ine lomba-lomba: kami minta maaf sudah lewat jendela, sementara ada pintu.

Jika dilakukan analisis pasca pembacaan, dapat dilakukan kategorisasi berdasarkan jenis dari ragam petuah bijak hasil inventarisasi yang terdiri atas 4 jenis yakni: (1) Petuah Bijak Lokal Daerah (Tolaki dan Sunda), (2) Petuah Bijak Nasional (Bahasa Indonesia), (3) Petuah Bijak Berbahasa Asing (Arab/Inggris), dan (4) Petuah Bijak Ciptaan Sendiri (Untuk Motivasi Diri). Terlihat bahwa terdapat petuah bijak yang sudah sangat familier, khususnya yang berbahasa Indonesia, maupun berbahasa Asing. Sementara beberapa petuah lokal khususnya yang berbahasa Tolaki adalah semacam Pe'olili (pesan-pesan leluhur), dan atau Bhitarandoka (Perumpamaan), yang merupakan ragam sastra lisan masyarakat Tolaki. Di sisi lain, terdapat semacam konstruksi motivasi diri yang sengaja diciptakan oleh para siswa dalam rangka memberikan semangat kepada dirinya, dan juga lingkungannya, sebagai medium penciptaan kerukunan. Hal ini cukup mencerminkan karakter bersahaja orang Tolaki yang dalam sebuah kearifan lokal disimbolkan dalam Kalosara, sebagai manifestasi kebersamaan (Subair, 2016). Tentu saja, ke semua petuah bijak itu diperoleh dari berbagai sumber, baik itu dari orang tua, pelajaran di sekolah, bacaan (sosial media, internet, buku, dll), inspirasi dari hobi (musik, film, blogger). Yang disebut terakhir adalah penjelmaan dari sebuah kreativitas siswa yang melahirkan gubahan-gubahan baru dalam menyusun dan membangun Marwah bijaksana dalam pengembangan literasi para siswa diwujudkan dalam segenap coretan-coretan siswa di berbagai media, yang pada akhirnya melahirkan karyakarya monumental mereka pada setiap jenjang kelas, mulai dari tingkat pertama sampai lulus.

Sesungguhnya, MA Pesri melalui OSIM dan Guru Bahasa Indonesia, sudah cukup memberi ruang kepada para siswa untuk mengekspresikan diri, dengan menyiapkan Majalah Dinding, dan mendukung penuh setiap siswa yang ikut serta dalam lomba-lomba penulisan sastra, serta dalam bentuk penugasan mata pelajaran bahasa Indonesia, berupa Cerpen, 
Puisi, Novel, dan Naskah Drama. Meskipun dari segi intensitas, masih perlu ditingkatkan. Namun begitu, wadah ekspresi literasi berbasis petuah bijak juga terlihat berbasis inisiasi, melalui pemanfaatan sosial media (di luar waktu sekolah) antara lain Quote romantik nan melankolis pada status Facebook, Twitter Instagram, Path, bahkan Wattpad dan Blog pribadi. Pada dasarnya, siswa Madrasah Aliyah Pesantren Ummu Shabri Kota Kendari memiliki kecenderungan mengembangkan literasi dengan model khusus berbasis coretan-coretan itu adalah model ekspresionisme terhadap fenomena yang telah dihadapi dan atau bahkan baru akan diarungi. Pengejawantahannya pun beragam, ada yang menuliskannya di halaman akhir buku-buku tulis, atau bahkan dengan menghadirkan tulisannya melalui buku-buku diari khusus dengan aneka warna, menuliskannya dalam status sosial media, blog, wattpad, dll. Namun yang menarik di antara ragam ekspresi itu, ternyata ada di antara para siswa yang memiliki kebiasaan menuliskan rangkaian kata-kata motivasi yang diciptakan sendiri melalui coretan yang ditulis sedemikian rupa pada kertas berwarna-warni, untuk selanjutnya ditempel pada meja-meja belajar, di dalam laci, bahkan di balik pintu lemari pakaian mereka.

"Sebenarnya, ada banyak sekali ruang ekspresi yang bisa kami manfaatkan dalam rangka pengembangan literasi dan pengamalan petuahpetuah bijak itu. Kami sering menulis pada majalah dinding, ikut serta dalam lomba-lomba karya tulis dengan tema tertentu, tugas-tugas dari guru khususnya mata pelajaran bahasa Indonesia, bahkan di antara kami ada yang menulis statusstatus fesbuk dengan sangat melo, serta mendayudayu, namun kami maklum, sebab ternyata ada pesan yang ingin disampaikan. Selain itu, di antara kami, ada yang memiliki kebiasaan menulis-nulis pada kerta-kertas berwarna, kemudian digunting sedemikian rupa, lalu ditempel di dalam laci, di meja kelas, bahkan di balik pintu lemari pakaian. Isinya, berupa curahan hati bahkan kata-kata mutiara, dan lain-lain. Ada beberapa yang boleh dilihat orang, ada juga yang sifatnya rahasia, sehingga meja yang ada tulisannya itu, selalu kami bawa serta ke kelas baru setiap kenaikan kelas" (Wawancara Helda Triastika, Siswi MA Pesri Kelas XII MIA).
Terlihat sekali, bahwa bangunan dasar pengembangan literasi siswa di MA Pesri sudah berjalan cukup baik, namun ada satu hal penting yang terlihat dari pernyataan Helda tersebut, bahwa terdapat sebuah ruang khusus yang dijadikan para siswa sebagai 'ajang curhat' dengan menulis pada bangku, laci, dan atau di balik-balik pintu lemari. Hal ini menjadi menarik, karena juga terdapat tulisan-tulisan bersifat rahasia, sebab boleh jadi, di sanalah ekspresi kebudayaan dalam pengertian yang sangat sederhana, bisa dimunculkan oleh siswa dalam melihat dan berproses dalam lingkungan tempat dia belajar.

\section{Pengembangan Literasi Siswa MA PESRI}

Budaya manusia tampaknya merupakan sistem yang paling kompleks di Jagad raya ini. Itulah sebabnya, menurut kaum humaniora, kebudayaan tak bisa dirumuskan secara tuntas dengan menggunakan sains kuantitatif belaka. Munculnya fenomenologi, hermeneutika, dan postrukturalisme di abad lalu, misalnya, merupakan upaya untuk memahami kompleksitas budaya itu secara rasional kualitatif. Ketiga pendekatan tersebut merupakan upaya-upaya mutakhir kaum humaniora untuk merasionalkan pemahaman mereka tentang budaya. Namun demikian, para ilmuwan tetap saja mencoba mereduksi budaya sebagai gejala biologis, berupa adaptasi manusia terhadap lingkungannya (Mahzar, 2006). Nah, yang terjadi di Pesantren Ummushabri adalah sebuah pengejawantahan konsep kebudayaan sebagai adaptasi atas aturan-aturan yang melekat (baca: ketat), sebagaimana telah dibahas sebelumnya. Di antaranya dengan secara tidak langsung membuat semacam tulisan-tulisan sederhana namun memiliki nilai positif dan berdampak pada pembinaan mentalitas siswa, baik yang menuliskannya, maupun oleh pembacanya. Mereka mungkin hanya sekadar berkreasi dengan menumpahkan buah pikiran atas nama motivasi diri. Namun yang mereka lakukan itu, sesungguhnya adalah proses adaptasi langsung terhadap aturan-aturan pondok yang sedemikian ketat dan padat, melalui coretan-coretan di balik laci, yang sengaja ditulis diam-diam, agar tidak ada orang lain yang tahu. 
Berikut adalah beberapa tulisan-tulisan siswa yang direduksi dari catatan-catatan mereka yang ditempel di meja-meja belajar, di dalam laci, bahkan di balik pintu lemari pakaian pada asrama.

- Kepercayaan itu seperti Kertas.. sekali kita remas, tidak bisa kembali sempurna...

- Berdoalah demi sakit hati, tapi jangan untuk menyakiti

- Sakit hati itu, ketika aku kehilangan kamu dan aku melihat kamu menyayanginya.

- Ninggalin yang BAIK, demi yang CANTIK? No Comment...

- Tulislah rencana terbaik untuk hidupmu, tapi izinkan Allah menghapus bagian yang salah dan menggantikannya dengan rencanaNya yang indah.

- Yaa Allah... aku berterima kasih atas semua orang yang telah engkau pertemukan denganku... ada yang menginspirasiku, mendorongku, melindungiku, mencintaiku, melupakanku, meninggalkanku, dan MENYAKITIKU... semuanya membuatku belajar menjadi orang yang lebih baik, semuanya membuatku memahami betapa indahnya hidupku...

- Separah apa pun luka... sesedih apa pun duka... seberat apa pun derita... tetaplah tersenyum dan bersyukur karena dengan cara itulah ALLAH mendewasakan dan menyayangi kita, agar menjadi hambanya yang tangguh, sabar dan ikhlas dalam menjalani ujian hidup.

- Orang Hebat adalah orang sedang "BERSEDIH" tapi tetap berusaha MEMBAHAGIAKAN orang lain

- Apapun yang terjadi nikmati hidup ini, hapus air mata berikan senyummu, kadang senyum terindah datang setelah air mata penuh luka.

- Sebanyak Apapun modal yang kamu punya jika kamu tidak tahu menggunakan, maka modal itu sia-sia

- Fokus: Belajar, Berdoa, Berusaha. Buktikan! Dont Forget to Smile

- Aku Sepi di Tengah Opini yang menganggapku ramah

- Aku Lebih Senang Berjalan dalam Hujan! Karena Hujan membuat air mataku tidak terlihat meski aku menangis.

- Berusaha untuk menjadi lebih baik, dan memperbaiki sepenuh hati
- "Semoga lancar kalau ujian, bisa berfoto pake baju toga kalau lulus".

- Tuhaan... Percepat waktumu hampir tidak tahan, kuatkan Tuhan!

- Now... I'm Haven't My Idol Support Studing...

- Dear Nabs... Semalam dering HP ku berbunyi. Antara senang apa tidak dia menelpon... tapi rasanya sakit... setiap hari hanya bisa makan hati... mendengar suaranya membuatku yakin dia hanya sekadar mempermainkanku! Hanya bisa menyimpan masalah sendiri... tak terbayangkan lagi rasa sakit saat ini... (22 Oktober 2015).

- Dear Nabs... Happy Anniv 11th Failed Nabs... Rasanya sakit dengan keadaan ini... Derita di atas tawa, menyakitkan bagiku! Katanya maaf atas segalanya! Apa kamu mengerti \pm 2 minggu!!! Hari-hari suram... penuh dengan air mata di setiap harinya... 232629 (23 Oktober 2015).

- Dear Nabs... Hari ini segala-galanya suram dimulai malam itu. Kesengsaraan menimpaku kegelisahan dimana-mana, bimbang yang sangat menyiksa. Maaf atas segalanya. Membuat orang menangis dan menangis karena orang lain... inilah yang terjadi saat ini! Detik ini! Menyakitkan! 232629 (Kamis, 05-11-2015).

- If God wants... in this world nothing IMPOSSIBLE, I Believe That!

- Dear Nabs.... Memegang suatu jabatan sungguh berat! Mereka tak mengerti bagaimana menjadi posisiku saat ini. Yang mereka tahu hanya duduk tenang dan diarahkan itu yang terjadi. Dianggap sebagai orang yang berkuasa itu sangat menyebalkan! Saya orang biasa! Manusia biasa! Yang berusaha menjadi yang terbaik, tapi sayang semuanya sirna membuatku tidak tahan hidup seperti ini! Ingin hidup bebas. (05 November 2015).

- Dear Nabs.... Min... Kapan sadapat teman seperti Kak Qurratun yang selalu ada untuk kamu? Mereka disini tidak seperti itu, tidak ada yang seperti kak Qurratun. Sa berharap dapat teman-teman yang seperti kak Qurratun! Saat ini saya mengerti kata mama orang yang sa selalu bantu meski sa marahi terus ternyata tidak begitu tulus terhadapku.... saya Minahku... SALAM RINDU! 
- Dear Nabs... orang yang menyuruhku ternyata dia juga yang menjauh, memang terkadang menyakitkan, membantu seseorang tapi tak terbalaskan satupun! Makasih atas segalanya... dunia berpihak kepada kalian, saya akan berusaha tidak mengurusi kalian. Nabs!

- I always love you whatever they tell, whatever i do, whatever you go!!

- I wish you good luck, Believe Allah is heaven... Dont ever underestimate your dreams and get your dream as high as possible... dont give up! You must keep praying and trying!

- Never say never! Nothing is easy... but impossible is nothing!!

- Sahabat jadi cinta itulah KETULUSAN. Cinta jadi sahabat itulah KEDEWASAAN.

- Terkadang cinta itu terbalas ketika rasa itu sudah terganti dengan sosok yang baru....cinta datang terlambat, Maaf.

- For you "Indry Joharni (Blonde)" and myself... my beloved sister and myself... "Untuk apa membenci seseorang yang pernah begitu kamu cintai. Kalau saja dengan membenci, kamu malah menjadi lebih tidak tenang. Biarlah dia berlalu, dengan menganggapnya sebagai kenangan. Semuanya akan lebih baik. Tidak perlu ada dendam. Meski memaafkan begitu susah. Lakukan pelan-pelan. Tanamkan pada dirimu bahwa dia hanyalah kenangan. Seseorang yang mungkin lucu untuk ditertawakan. Hingga suatu hari ini atau nanti, tanpa terasa berat lagi, tanpa perlu membenci dia, kamu sudah sampai pada titik... dimana ternyata kamu sudah tidak mencitainya lagi, Fighting... Salam Manis: Gita”.

- $\quad$ Sekarang... JARAK yang memisahkan kita, namun suatu saat kita akan berkumpul dalam suatu KEBAHAGIAAN. Love You Mom and Dad!.

- Allah menitipkan kelebihan di setiap kekurangan, menitipkan kekuatan di setiap kelemahan, menitipkan sukacita di setiap duka cita, menitipkan harapan di setiap keraguan. Allah berjanji semua akan INDAH pada waktunya

Ketika didalami, maka akan terlihat bahwa terdapat begitu banyak "emosi" yang bermain-main dalam segenap tulisan-tulisan para siswa tersebut di atas, di dalamnya mengandung unsur-unsur curahan hati, ketegaran, kesedihan, kepercayaan diri, kerinduan, amarah, bahkan semangat perlawanan, tentunya dengan berbagai latar 'problem' yang dihadapi. Jika dibaca dari kacamata anak muda kekinian, boleh jadi ada yang merepresentasikan tulisan-tulisan itu dengan melihatnya sebagai tulisan-tulisan 'lebay', karena terkesan mendayu-dayu dan cengeng. Tapi di sisi lain, tulisan-tulisan itu, tidak bisa hanya dilihat sebagai objek tunggal yang berdiri sendiri, sebab dia sangat melekat dengan lingkungan tempat tulisan itu dihasilkan. Belum lagi jika dikaitkan dengan kondisi MA Pesri sebagaimana telah digambarkan di bagian awal Paper ini. Kita harus bisa menerjemahkannya dalam situasi sekolah dengan aturan-aturan yang super ketat karena terdapat banyak sekali batasan-batasan yang tidak boleh dilanggar oleh para siswa/santri. Pada saat yang sama, juga harus dilihat sisi normatif dari aturan itu sebagai sebuah pilihan yang telah ditetapkan sebagai 'alat' untuk membentuk karakter siswa ala MA PESRI. Hal ini sejalan dengan 'pesan' yang disampaikan oleh Fairclough bahwa sebuah teks bukan hanya menampilkan bagaimana suatu objek digambarkan tetapi juga bagaimana hubungan antar objek didefinisikan yang merujuk pada 3 elemen: representasi, relasi, dan identitas.

Anak-anak Ummushabri, sepertinya sedang ingin 'menyampaikan' pesan, tentang kompleksitas masalah yang dihadapinya, seperti makna yang ingin disampaikan salah seorang siswa "Separah apa pun luka... sesedih apa pun duka... seberat apa pun derita... tetaplah tersenyum dan bersyukur karena dengan cara itulah ALLAH mendewasakan dan menyayangi kita, agar menjadi hambanya yang tangguh, sabar dan ikhlas dalam menjalani ujian hidup". Ada semacam pertautan sarat makna antara curahan hati, kondisi lingkungan, dan permainan perasaan yang terjadi (Wachid, 2005). Bisa saja itu dibaca secara gamblang dengan melihatnya sebagai sebuah pesan luhur tentang ketegaran semata, namun di sisi lain kita juga bisa menemukan 'tekanan dan kepasrahan' yang bisa disebabkan oleh apa saja, entah itu lingkungan, aturan, atau bahkan kegagalan. "Saya menulis tulisan-tulisan itu, tidak sekadar iseng, apalagi 
supaya terlihat ekses atau gaya-gaya. Tulisan itu bisa dikatakan jelmaan dari apa yang saya alami, teman saya alami, dan dari apa yang saya lihat dan dengarkan selama di pesantren" (Fitrah Lapau, Siswi MA PESRI Kelas XII MIA)

Sebenarnya, beberapa tulisan itu jika direpresentasikan, juga terdapat beberapa karya yang menunjukkan fungsi reflektif semata, atau dengan kata lain bahasa yang ditampilkan adalah makna sebenarnya, seperti If God wants... in this world nothing IMPOSSIBLE, I Believe That!, ini tentang keyakinan akan kehendak Tuhan atas sesuatu yang bisa diterjemahkan sebagai penghambaan dan kepercayaan penuh. Hal lain misalnya dalam "Sakit hati itu, ketika aku kehilangan kamu dan aku melihat kamu menyayanginya". Pernyataan itu adalah refleksi atas apa yang dilihatnya dengan mata kepala secara langsung, yang secara kebetulan menyentuh hatinya yang terluka, sehingga diciptakanlah petuah penghibur diri. Di samping itu, beberapa tulisan juga bisa 'dibaca' melalui pendekatan intensional atau sebuah representasi atas bantahan pada keadaan yang berlawanan. Allah menitipkan kelebihan di setiap kekurangan, menitipkan kekuatan di setiap kelemahan, menitipkan sukacita di setiap duka cita, menitipkan harapan di setiap keraguan. Allah berjanji semua akan Indah pada waktunya. Tulisan ini memiliki makna sangat dalam, dengan mengambil sisi positif atau hikmah di setiap keadaan, seburuk apa pun itu. Contoh lainnya bisa dilihat dalam: "Aku Sepi di Tengah Opini yang menganggapku ramah". Sebuah pernyataan memosisikan diri berbeda dengan persepsi orang atas dirinya.

Selanjutnya, beberapa tulisan juga mencerminkan pendekatan konstruksionis, atau fungsi-fungsi perbaikan, antara lain "Berdoalah demi sakit hati, tapi jangan untuk menyakiti", "Berusaha untuk menjadi lebih baik, dan memperbaiki sepenuh hati". Demikianlah, ragam karakter pembacaan kita atas tulisan tersebut tentu selain harus melihat tulisan apa adanya, juga harus disesuaikan dengan karakter masing-masing kita, serta sudut pandang masing-masing dalam melihat fenomena. Perbedaan tentu menjadi sesuatu yang niscaya. Yang pasti, bahwa apa yang dituliskan ini, ketika dikaji lebih mendalam bisa saja dijadikan sebagai alat ukur perkembangan kebudayaan di Pesantren Ummushabri, melalui kreasi yang diejawantahkan dalam tulisan-tulisan di balik laci, yang dihasilkan dan diciptakan oleh latar lingkungan yang sama (baca: pesantren), dengan kondisi dan karakter menulis yang berbedabeda. "Beberapa tulisan tentu boleh dibaca oleh teman-teman, bahkan guru, namun beberapa yang lain sengaja dirahasiakan, demi menghindari hal-hal yang tidak diinginkan". (Bagaimanapun, siswa-siswi PESRI telah mempertunjukkan sebuah implementasi pengembangan literasi dengan mengeksplorasi media-media yang disediakan lingkungannya untuk tidak berhenti berkreasi meski berada di tengah keterbatasan, dan 'keterpenjaraan'. Bahkan, dengan kondisi yang sedemikian 'sibuk' itu, mereka mampu menerjemahkan kesedihan menjadi ketegaran, kerinduan menjadi kebahagiaan, luka menjadi motivasi, dan tekanan bukan lagi beban yang harus diterima, namun juga harus diubah menjadi simbol semangat. Menariknya, semua itu dielaborasi dengan sangat apik melalui ekspresi bijaksana dalam tulisan-tulisannya, yang tentu tidaklah berlebihan jika menyebutnya sebagai 'petuah bijak ala siswa" yang diciptakan untuk bertahan, dan menguatkan diri, serta lingkungannya.

\section{PENUTUP}

Varian petuah bijak pada siswa Madrasah Aliyah PESRI, menunjukkan keragaman dari segi jenis, sumber, dan inspirasi. Berdasarkan jenis dari ragam, petuah bijak hasil inventarisasi yang terdiri atas 4 jenis yakni: (1) Petuah Bijak Lokal Daerah (Tolaki dan Sunda), (2) Petuah Bijak Nasional (Bahasa Indonesia), (3) Petuah Bijak Berbahasa Asing (Arab/Inggris), dan (4) Petuah Bijak Ciptaan Sendiri (Untuk Motivasi Diri). Terlihat bahwa terdapat petuah bijak yang sudah sangat familier, khususnya yang berbahasa Indonesia, maupun berbahasa Asing. Sementara beberapa petuah lokal khususnya yang berbahasa Tolaki adalah semacam Pe'olili (pesan-pesan leluhur), dan atau Bhitarandoka (Perumpamaan), yang merupakan ragam sastra lisan masyarakat Tolaki. Di sisi lain, terdapat semacam konstruksi motivasi diri yang sengaja diciptakan oleh para 
siswa dalam rangka memberikan semangat kepada dirinya, dan juga lingkungannya, sebagai medium penciptaan kerukunan.

Pengembangan budaya literasi siswa MA PESRI dapat dilihat pada kreasi berbasis inisiatif yang dituliskan siswa pada berbagai media, yang di dalamnya mengandung keluhkesah, juga simbol beratnya beban yang harus diemban oleh siswa atas ketatnya aturan-aturan pesantren, yang dibahasakan melalui curahan hati. Penelitian ini juga melihat transformasi pemaknaan dari siswa atas petuah bijak masa lalu, yang didesain ulang dengan tata bahasa yang dibuat sendiri sebagai simbol motivasi dan ekspresi bijaksana, yang bisa ditemui di balik laci, dan pintu-pintu lemari, serta tempat-tempat lainnya. Dalam aspek yang lebih luas, coretancoretan itu menggambarkan semangat juang tinggi dari para anak-anak pesantren di kehidupannya yang sangat dinamis dan penuh liku.

\section{UCAPAN TERIMA KASIH}

Penulis mengucapkan terima kasih kepada semua pihak yang telah memberi dukungan terlaksananya penelitian ini. Khususnya kepada Kepala Balai Litbang Agama Makassar (DIPA), Pengasuh Pesantren Ummushabri Kota Kendari, kepada para siswa yang tulisannya telah menjadi inspirasi riset ini. Secara khusus kepada para pihak yang namanya tidak bisa disebutkan satu persatu telah memberikan informasi baik teknis maupun non teknis terkait penelitian dan hal lain yang bersifat metodologis demi menunjang riset ini.

\section{DAFTAR PUSTAKA}

Anonim. 2016. Ummushabri dalam Kilasan Sejarah, dokumen tidak diterbitkan.

Apriani, Eka. 2016. A New Literacy: The Role of Technology to Develop Student's Character. dalam Ta'dib: Journal of Islamic Education, Volume 21, Number 1, June 2016.

Asad, Muhammad, dkk. 2012. "Nilai-nilai Keagamaan dalam Petuah Bijak, Puisi dan Peribahasa se Kawasan Timur Indonesia. Laporan Penelitian Balai Penelitian dan Pengembangan Agama
Makassar. Bidang Lektur dan Khazanah Keagamaan.

Cresswell, John W. 1994. Research Design, Qualitative and Quantitative Approaches.

California: Thousand Oaks.

Fairclough, Norman. 1992. Discourse and Social Change, Cambridge, Polity Press.

1995. Media Discourse. London: Edward Arnold.

1998. Discourse and Text: Linguistic and Intertextual Analysis within Discourse Analysis, dalam Critical Discourse Analysis, London and New York, Longman.

Hall, Stuart. 2003. "The Works of Representation". Representation: Cultural and Signifying Practice. Ed. Stuart Hall. London: Sage Publication.

Hill, S. (2006-2008). Developing Early Literacy: Assessment \& Teaching. Prahran, Vic: Eleanor Curtain Publishing.

Hutomo, Suripan Sadi. 1991. Mutiara yang Terlupakan: Pengantar Studi Sastra Lisan. Surabaya: HISKI Jawa Timur.

Jenkins, H. 2006. Convergence Culture: Where Old and New Media Collide. New York, NY: New York University Press.

Latifah. 2014. Analisis Literasi Media Televisi Dalam Keluarga. Studi Kasus Pendampingan Anak Menonton Televisi di Kelurahan Sempaja Selatan Kota Samarinda. eJournal Ilmu Komunikasi, Volume 2, Nomor 4. 259-268.

Luke dan Feebody. Programme for International Student Assessment (PISA)

Mahzar, Armahedi. 2006. Melacak MutasiMutasi Meme. Dalam Adlin, Alfatri (ed). Resistensi Gaya Hidup: Teori dan Realitas. Jalasutera: Yogyakarta.

Muslim, Abu. 2013. Artikulasi Religi SajakSajak Basudara di Maluku. Jurnal Alqalam Balai Litbang Agama Makassar, 2013.

New South Wales Education \& Training. 2010. Litearcy Learning \& Technology.

Pramono, Silvester Novi. 2016. Meliterasikan Generasi: Saat Literasi jadi Modal. Universitas Katolik Widya Mandala Surabaya. Artikel http://ukwms.ac.id/meliterasikan- 
generasi-saat-literasi-jadi-modal/.

Diakses 9 November 2016).

Ratna, SU. Nyoman Kutha. 2011. Antropologi Sastra: Peranan Unsur-unsur Kebudayaan dalam Proses Kreatif. Yogyakarta: Pustaka Pelajar.

Subair, Muhammad. 2016. The Attitude of Peacefullness In The Transformation of Kalosara's Value in A Traditional Dance 'Lulo', Kendari, Southeast Sulawesi. International Symposium of Religious Life (ISLR). Center for Research and Development of Religious Life, Ministry of Religius Affairs of the Republic of Indonesia. Jakarta, 5-7 October 2016.
Sugiyono. 2010. Metode Penelitian Pendidikan (Pendekatan Kualitatif, Kuantitatif, dan $R \& D)$. Bandung: Alfabeta.

Suyono. 2009. Pembelajaran Efektif dan Produktif Berbasis Literasi: Analisis Konteks, Prinsip dan Wujud Alternatif Strategi Implementasinya di Sekolah. Jurnal Bahasa dan Seni, tahun 37. Nomor 2. Universitas Negeri Malang.

Wachid B.S., Abdul, 2005. Membaca Makna (dari Chairil Anwar ke A. Mustofa Bisri). Grafindo Litera Media: Yogyakarta.

Wardi, Tati D. 2013. "Paradigma Baru Literasi". Dimuat di Koran Tempo, Sabtu, 30 November 2013). 
224 | Jurnal “Al-Qalam” Volume 25 Nomor 1 Juni 2019 